ISSN: $2450-6869$

eISSN: $2719-6763$

DEFENCE SCIENCE REVIEW

http://www.journalssystem.com/pno/

No. 10,2020

DOI: $10.37055 / \mathrm{pno} / 133800$

\title{
Polish national character in the context of state defence
}

\section{Original article}

Accepted: 25 November 2020

Published: 14 December 2020

\section{Peer review:}

Double blind

\section{Keywords:}

national character of a Polish soldier, human factor in defence systems, material factor in defence systems, ethnocentrism, ethnopsychology, national honour, army morale, defence potential, national identity of a soldier

This work is licensed under the Creative Commons AttributionNonCommercial-NoDerivatives 4.0 License

\author{
Krzysztof Komorowski ${ }^{1}$ \\ ORCID (iD) 0000-0003-0707-4275
}

Military University of Technology in Warsaw,
gen. Sylwestra Kaliskiego 2, 01-476 Warszawa

Abstract

Objective: Demonstration and analysis of the impact of the human factor on the effectiveness of the state defence system.

Method: Literature research and critical analysis.

Results: The research demonstrates that the human factor is the most important component of the state defence potential. This thesis is corroborated by examples from the history of Poland, and supported with philosophical, ethical and ethnographic considerations. Based on the examination of the selected research group consisting of Polish soldiers, qualities important for Poles, such as honour, righteousness and patriotism, which are at the foundation of the national character of a soldier, have been identified. On the other hand, the article also takes into account negative stereotypes and opinions presented in the literature regarding the national character of the Polish soldier.

Conclusions: The conducted research and analysis prove the unquestionable domination of the human factor in state defence and military systems. It has been shown that, apart from the demographic potential and mobilisation capabilities, an important aspect of the human factor for defence is the national character and the morale of the army, which should be prioritised over material aspects. Honour, both in the axiological dimension of the sense of pride, dignity, nobility, and diligence, as well as in the sense of an ethical virtue in people's mentality and the morale of soldiers, shapes consciously determined attitudes and behaviours.

\footnotetext{
1 Prof. Krzysztof Komorowski, Sc.D., Institute of Security and Defense Systems, Military University of Technology in Warsaw. An artillery officer by education, he deals with the history of the army and the art of war, geostrategy, international relations, contemporary armed conflicts. He is the author of over 300 publications. E-mail: krzysztof.komorowski@wat.edu.pl.
} 


\section{Basic thesis and discussion}

History has shown that the human factor, in particular, the national character and the morale of the army, has the paramount impact on the defence capabilities of the state.

The invaluable role of the morale of the nation and the army for state defence was emphasised by the victorious commander in the Polish-Bolshevik war of 1920, Marshal Józef Piłsudski, who said that: "One of the greatest tasks of every nation and every state at war is taking care of the moral aspect of people's attitude to war. I shall mention here a famous quote by Napoleon, which sometimes seems contradictory, and yet is so often demonstrated to be true in the history of every war. Napoleon used to say that in war, three-quarters of victory is down to morale, and only one can be attributed to all other factors". ${ }^{2}$

A great admirer of Napoleon Bonaparte, and a 19th-century French military theorist, Colonel Charles Jean Ardant du Picq agreed with this thesis, saying that: "Combat is the ultimate goal of the armed forces and man is the primary instrument of combat; nothing can be wisely prepared in an army - establishment, organization, discipline, tactics, all things that are like the fingers of one hand - without the exact knowledge of the primary instrument, man, and his moral state at this definitive moment of combat" (Ardant du Picq, 1927).

On the other hand, the legendary commander of the Allied forces, General Dwight D. Eisenhower, after the experiences of World War II, concluded that the defence potential of a given state is the product of: moral strength, military strength and economic strength of the nation. However, if the value of any of the factors were zero, then, of course, the whole product would also equal zero according to the formula $\mathrm{DP}=3 \mathrm{~S}(\mathrm{mo}) \times \mathrm{S}(\mathrm{mi}) \times \mathrm{S}(\mathrm{e})$. As can be seen, Eisenhower, assigned to moral strength three times as great importance as to military strength (Parys, 1992, pp. 64-80). Naturally, the moral strength of the nation should be understood in a broad sense, taking into account the national spirit, the moral state of the nation along with virtues such as patriotism, dignity and honour, the degree of selfidentification with one's homeland and national identity, as well as the morale of the army. In this self-examination of the national conscience, in addition to its distinguishing virtues, one must also take into account its cardinal sins, defects and weaknesses. This is undoubtedly related to the political aspect, including political attitudes and motivations to defend one's own state with common good in mind. Political leaders, eminent figures, moral authorities and the elites - as the backbone of the nation and entities capable of independent judgment -

\footnotetext{
2 J. Piłsudski, O Wodzu Naczelnym i państwie, odczyt w Warszawie 15 kwietnia 1926 r., Pisma zbiorowe, tom VIII, Warszawa 1937, p.318-319.
} 
have an overwhelming influence on the patriotic sentiments and attitudes of the society. Without them, the nation becomes but a passive instrument for the domestic and foreign powers.

What deserves attention are the American studies on the state defence capabilities and the assessment of the perceived geopolitical power and the contribution made by Ray Cline from the US Department of State and CIA to the discipline. Cline put forward a formula for the perceived power of states, which is the product of the sum of the material factor (the socalled critical mass, including population and territory), economic and military capacity and the sum of the national strategy coefficient and the society's will to pursue the national strategy. The emphasis on the decisive role of the last factor seems obvious, though not to all political and military decision makers.

The American nomenclature of the state's defence potential was an inspiration for the famous Polish geopolitician, Leszek Moczulski, who presented a similar method of assessing the state's defence capabilities as the product of material, intellectual and moral potential (Moczulski, 2008, pp.69-80). What is worth to point out is that in this formula the intellectual potential is separated from the moral (spiritual) state, but their sum constitutes the crucial human factor for the state defence system.

A somewhat modified approach to the assessment of the importance of the human factor for the state's defence capabilities was adopted by Rupert Smith, a British commander and military theorist. After an analysis of historical examples of the sources of strength and weakness of the state and its army, he synthesised the results in a formula, where the state's power is the product of three factors: potential (means), methods (techniques, principles, forms of using available means) multiplied by two (thus twice as important), and will understood as volitional features and morale (spirit) - multiplied by three (Smith, 2010, pp. 270-290). Although Smith referred to the experiences of contemporary armed conflicts, he did not overlook the political and military aspects of state defence.

While, as has been demonstrated above, many theorists place the human factor in the centre of defence and military systems, it is worth to define first what is actually understood by this term. In the context of the defence system of the Republic of Poland, the human factor can be understood as the total population who identifies with the Polish raison d'État and the interests of the Polish nation. The core of the entire state's military security system is invariably its armed forces and the mobilisation potential in times of crisis, war and armed conflicts. 
As has been mentioned earlier, the generally accepted measure of importance of the human factor for defence, apart from the demographic potential and mobilisation capabilities, is the national character and the morale of the army, prioritised over material capabilities.

However, researchers usually stress diffuculties involved in defining these terms. In his closing remark at the academic debate devoted to the Polish national character in 1983, Wojciech Wrzesiński concluded that: "What is worth noting is that no lecture nor discussion has attempted to define the term "national character"' (Wrzesiński, 1984, p. 214; Wierzbicki, 2010, pp. 290-291). Experts on the subject agree that the category of "national character" does not have a scientific status.

On the other hand, the literature on the subject offers numerous explanations of the term. Almost every single author puts forward his own definition of the concept. Nevertheless, most of them are contextual references to selected evaluation criteria, while some can even be regarded as intentional terms. This can be a dangerous practice.

Such practices can be dangerous as they carry the risk of possible misuse and manipulation, especially in comparative references to Polish people and their neighbours from a historical perspective. Instead of an objective scientific observation, one can be left with an idealised self-portrait of a Pole and a critical, prejudiced image of neighbouring nations or national minorities, which can lead to egocentrism, polonocentrism, and even ethnocentrism, as well as perpetuate harmful stereotypes.

An original reflection on Polish national character was offered by Father Józef Tischner. Being under the influence of romanticism, he understood the national character as the basic premise for the existence and survival of the nation. "What is then the national character?", he asked. "It is much more than a mere disposition, mood or temperament. It is the willingness to try, which resembles an instinct of life. People do not feel this instinct every day, but when they do, they want to have their national character. This desire lies at the foundation of nations. Nations shall live as long as they want to preserve their national character. When they abandon it, they die" (Tischner, 2001; Wierzbicki, 2010, p. 299). Although the above is not a classic definition of the national character, it offers a very accurate analytical observation regarding its exceptional importance for the existence of the nation state.

Valuable insights into the topic are offered by philosophical and historical reflections that seek the meaning of existence and passing in the context of continuity and changeability. The reconstruction of philosophers' views on the state, nation, international order and war provides an appropriate basis for considerations regarding the importance of the national 
character for military security. The historical experience shows that only mature nations in the Aristotelian sense can attain the highest level of security. Therefore, the character of mature nations with a military and creative spirit is conducive to the security and stability of the state. Aristotle argued that young nations with a military spirit, but devoid of creative predispositions, despite their temporary military successes, often fall victim to prosperity and corruption in times of peace ${ }^{3}$.

For the purposes of this article, the national character will be defined as a set of distinctive and dominant psychological traits, situational predispositions, qualities and moral values that are revealed in attitudes towards imperatives and requirements of the state's and nation's interests (raison d'état), in the style of service, work and everyday life, as well as in the capabilities of mobilisation against threats and in the fight to defend one's homeland. What is valuable in this regard is historical experience, although it should be remembered that the assessment of the Polish national character from a historical perspective is quite risky, since the Republic of Poland used to be a multinational, multicultural, multi-religious and even multi-state organism. On the other hand, genetic research proves that members of different nations and ethnic groups may share similar genotypes. Reducing ethnic differences to physical and biological variations (determining the psychological capabilities of a nation) through anthropology, eugenics and ethnopsychology may lead to racism and racial segregation (Bieleń, 2015, pp. 127-128).

Acclaimed Polish anthropologists and eugenics theorists associated with Roman Dmowski's camp: Ludwik Jaxa-Bykowski and Karol Stojanowski carefully studied the issues of Nazi racism in relation to Polish nationalism. Just before the outbreak of World War II in 1939, Karol Stojanowski, an associate professor at the University of Poznań, wrote: "Reading Hitler's book, one involuntarily starts to compare it to the Polish national ideology and the behaviour of the Polish national camp. And I am pleased to say that our movement has nothing to lose from such a comparison, but a lot to gain. One has to keep in mind that the Polish national movement has had to overcome obstacles that the Nazis had never even imagined. It is enough to say that Germans lived in their own state with a uniform political structure since 1870. In contrast, the Polish national movement managed to develop its own, much more profound ideology sooner than Germany and filled with it the nation at large"4.

\footnotetext{
3 Aristotle's view was recalled by Janusz Świniarski in an interesting essay: Bezpieczeństwo a charakter narodowy Polaków (Security and the Polish national character), published in a collective work edited by Tadeusz Szczurek (Szczurek, 2009, p. 23).

${ }^{4}$ Dr K.Stojanowski, Polsko-niemieckie zagadnienia rasy, Poznań, Katowice 1939, p. 25.
} 
Due to the discredit of criminal racist theories and the atrocities of genocide committed during World War II, the physical and biological determinism is perceived today only in terms of multiculturalism, though some find it disputable. ${ }^{5}$ This means that it is cultural differences that determine the character of different nations, which, in turn, leads to an optimistic conclusion regarding the possibility of influencing personality traits and behaviour of large human groups not only in the context of globalisation and migration, but also in the context of a risk society and all the external and internal threats it brings, such as terrorism or pandemics.

As regards the theory and history of the Polish national character and the factors that shaped it, what might be helpful are the findings of the British ethno-psychologist and historian Sir Ernst Barker (Barker, 1963, pp. 3-40).

Reflections on the character, disposition and habits of the peoples inhabiting the area between the Oder, the Bug, the Baltic Sea and the Carpathians can be found in the earliest works of historiography. Their first authors were foreign travellers, missionaries, military men and merchants. The opinions of foreigners about Poles were undoubtedly a valuable source of information for the rulers and army commanders of the neighbouring countries. They have also proved useful in the reconstruction of the Polish self-portrait. One of such noteworthy works is the extensive collection of reports and opinions of foreigners made throughout the entire millennium of the existence of the Polish state, published in the compilation by Jan Gintel (Gintel, 1971). Another work worth mentioning, written by Andrzej Wierzbicki, presents the Polish historiography of national characterology (Wierzbicki, 2010).

When it comes to the society of the Polish-Lithuanian Commonwealth in 1569-1795 (during the Polish-Lithuanian Union), attention is usually focused on the characteristic traits of the nobility, who was responsible for the security of the state and could initiate mass mobilisation. It was only the birth of a modern nation and the Second Polish Republic in the 20th century, that allowed to fully describe the Polish national character in terms of volitional features with all its virtues and flaws shaping the attitudes of the community towards threats and challenges of the changing reality.

What is also of paramount importance is the axiological dimension of the national character and the morale of the army, defined by ethical virtues, such as: sense of pride, honour, dignity, nobility, generosity, empathy, righteousness and honesty. It is these virtues that help to shape specific personality traits of the community and individuals. A special

\footnotetext{
${ }^{5}$ References to race seem to be present only in the discussions of anthropologists and geneticists, as well as in
} 
"glue" that binds the nation and the state together is patriotism - the feeling of love to the homeland (Bocheński, 1994, p. 49; Komorowski, 2019, pp. 45-60).

According to the 19th-century historian Joachim Lelewel, it was the "elusive, lively spirit of the nation" that had always been a distinguishing feature of the Polish national character in Europe. On the other hand, what is somewhat unclear is the author's approach to the national character as a set of features characterising the dominant majority. Lelewel emphasized that the strength of the nation is determined not only by the size of the population, but above all by intellectual capabilities. What lies at the core is the "national identity", defined by Lelewel as a set of properties that distinguish one nation from another (Lelewel, 1964, pp. 312-388; Wierzbicki, 2010, pp. 84-87). Marceli Handelsman wrote about the "development of modern nationality" in Poland, stressing that - from the physical point of view - a community is the sum of its members. This is contrasted with the psychological point of view, which brings out a specific cross-section of people's traits and predispositions (Handelsman, 1924; Handelsman, 1928). In turn, Tadeusz Łepkowski, in the conclusion of his considerations on the Polish national character, wrote: "In the eighth decade of the last century [19th century], the modern Polish nation, which had been born in the times of tragedies, but boasted a great, unique culture and distinctive traits of the collective mentality, should have been foretold that it would have a difficult childhood and a turbulent youth. One should spare it prophesies of an imminent death. For it had learnt to be tough and resistant already in its cradle" (Łepkowski, 1957, p. 507; Wierzbicki, 2010, p. 287).

However, the "spirit of the nation", or its soul, may turn out to be a conceptual misuse if one were to assume its identity with the souls of individual Poles. After all, a nation is not a collection of clones, but a community of individuals diverse in terms of psychological traits and moral values (Świniarski, 2009, p. 21). Similar associations can be regarded as an overinterpretation of the Platonic interpretation of the state and the citizen. Therefore, when describing the Polish national character, one should capture the dominant, characteristic traits of Polish people in the light of historical events and experiences. Undoubtedly, the geopolitical location of the Republic of Poland between the West and the East was conducive to the development of such traits of Poles as directness, openness, tolerance, love of freedom, as well as the proverbial hospitality (as a famous proverb goes: a guest in the house is God in the house), which can also be related to the moderate climate, fertile soils and open space.

medicine, pharmacology and zoology. 
Thus, the Polish national character was not constant. On the contrary, with passing time and under the influence of external factors, it constantly evolved. What had a particular impact on it were long-term migrations of people, ethnic cleansing, colonisation, and finally wars, partitions, occupation, as well as totalitarianism.

That is why the glorious pages of Poland's history should be regarded with a hint of national egoism, and the true heroes of those times should be held up as models in national education, fostering the sense of mission and even national pride. As Zygmunt Balicki put it, "it is not the one who wears a uniform and carries a sword who is a true soldier, but the one who has the spirit of a soldier". What he had in mind, of course, was not a mercenary, but a soldier who was also a model citizen and a patriot, willing to sacrifice his life, health and property for the good of the homeland. Another representative of Polish nationalists, Ludwik Jaxa Bykowski, emphasised the role of raising awareness and teaching the norms of behaviour as a source of proper attitudes, decisions, behaviours and actions. What he considered to be of greatest importance were steadfastness, firmness and the ability to uphold one's honour, follow norms and demonstrate proper attitudes (Jaxa-Bykowski, 1938, pp. 610). The idea of national education became the hallmark of the entire camp of Roman Dmowski.

Taking into account the variability of the national character under the influence of political, economic, geographic and climatic conditions, as well as migration, wars and occupation, it is reasonable to adopt Aleksander Bocheński's correlation between civilisational development and the mental attitude of the nation towards state defence (Bocheński, 1972).

What is interesting is the research postulate of the relationship between the national character and national identity in the context of the dynamics of environmental changes and civilisational development. Undoubtedly, the phenomenon of national identity - commonly associated with the sense of belonging to a given community of people aware of the raison d'etre of their homeland as a common good - serves the interests of the state, ensuring its stability and defence capabilities. Therefore, the criteria of the national identity of Poles and other nations should be examined from a comparative perspective, abandoning various myths and stereotypes related to it. In the existing studies, the basic criterion of Polish identity, or the so-called Polishness was emotional self-identification with the nation, a sense of belonging. According to a survey conducted in 2005 , this feeling was experienced by $84 \%$ of 
the respondents ${ }^{6}$. Also, the majority of the respondents (69.1\%) linked Polishness with blood ties (i.e. having Polish ancestors), as well as shared elements of culture, such as common language $(87 \%$ of the respondents considered knowledge of the Polish language to be one of the criterions of Polishness). Other important aspects were the place of birth and permanent residence in one's homeland and - in the sphere of culture - also the knowledge and preservation of Polish national and military traditions through emotional identification with the past, pride in glorious moments in the history of one's homeland and drawing lessons from its shameful episodes (79.6\% of the respondents). Poland is a country where national identity was linked with religious identity, giving rise to the self-stereotype of a Pole Catholic.

The demise of the Polish-Lithuanian Commonwealth in the 18th century is a good example of the relationship between the national character and Polish self-identification. It turns out, however, that the popular opinions on the national character of the Commonwealth, especially with reference to the aristocracy and nobility, were burdened with political and ideological biases. It is difficult to be objective, when various myths and stereotypes about Poles persistently proclaimed by Poland's neighbours are so prevalent. It is true that the 18th century saw a depravation of the ruling elites, with the selfishness of the magnates, servile attitude of the elected kings and the anarchy of the nobility. The Wettins broke the national spirit through the moral decay of the petty nobility who owned no land, prioritisation of private interests over the sense of service and responsibility for the fate of the Republic of Poland and over the honour of the knightly ethos. Foreign courts and magnates contributed to that decay through political corruption, transforming the democratic state into a PolishLithuanian-Russian magnate oligarchy, where harmful clientelism developed ${ }^{7}$. At the same time, negative opinions were spread about the irresponsibility, indolence, incompetence, laziness, indolence, irascibility and rowdiness of Poles, allegedly incapable of independent development.

When, after 1717, a law reserving the offices of the Commonwealth exclusively for Catholics came into force, the ruler of Prussia, Frederick II, and later also the Russian empress Catherine II, used it as a pretext to attack the Polish nation for intolerance and religious discrimination, which were in stark contrast to the ideals of the Enlightenment, as

\footnotetext{
${ }^{6}$ Tożsamość narodowa Polaków oraz postrzeganie mniejszości narodowych i etnicznych w Polsce, Survey report (prepared by: M. Strzeszewski), CBOS, Warszawa 2005; see more in: J. Błuszkowski (Błuszkowski, 2005, pp. 120-140).

${ }^{7}$ Cf.: A. Mączak (Mączak, 1940).
} 
well as of immoral conduct and the inability to exist as a sovereign state. In this way, hostile powers justified the future partitions of the Republic, going as far as to use the theory of the character-shaping influence of climate. One of the many critics of the Polish nation was the Piarist Ubaldi Magnonii, who, under the patronage of King Augustus III of Saxony, argued in his dissertation Nocticum Sarmaticarium Vigiliae (Braniewo - Warsaw 1751) about the alleged intellectual disability of Poles compared to other nations due to the unfavourable climate. The well-established stereotypes of Poles were perpetuated also after the partitions, under foreign rule, as exemplified by the statements of the great admirer of Frederick II, the philo-Russian Prussian officer Carl von Clausewitz, in his work "On War" (Clausewitz, 1995, pp. 449-450). What is shocking, these subjective opinions, denying Poles the right to their own statehood, are still uncritically invoked even to this day (Marczak, 2013, pp. 18-26).

It is worth remembering that at that time it was the Bar Confederates under the command of Kazimierz Pułaski who initiated the anti-Russian uprising in defence of the independence of the homeland and the Catholic faith, sacrificing their lives, property, risking death or banishment. It was the enlightened Polish elites who led to the historic reforms of the Great Sejm and the Constitution of 3 May 1791. Poles also proved their military skills and bravery in defending the homeland against Russia's military intervention. They did not spare blood and bravery in the last stand for independence during the Kościuszko Uprising in 1794, in line with the oath to God and the Commander-in-chief of the National Armed Forces calling to defend the homeland until one's last breath. The defeat at the battle of Maciejowice sealed Poland's fate and led to the last partition in 1795. But it was not the weakness of the character of Poles, but the difference in military and economic potential between Poland and the aggressors, as well as the swaying leadership that were the direct causes of Poland's downfall. There were numerous reasons for those differences, but their analysis is beyond the scope of this study.

Polish soldiers gave testimony to their best traits of character during the Napoleonic wars, fighting bravely to regain independence for their homeland. Neither the bitter defeat of the Emperor, nor the post-partition occupation as a result of the Vienna Peace, lasting over a hundred years, did not break Poles. On the contrary, in spite of the theories about the degeneration of the nation under foreign rule and the discrimination that it faced, Poles did not lose their national character and, inspired by patriotic sentiments in the spirit of romanticism, summoned up their courage for heroic deeds, fighting for independence and demonstrating their will to be a free nation once again. Just before the rebirth of the Republic of Poland, Zygmunt Balicki wrote: "What kind 
of practical morality should be instilled in the hearts of the young generation? In our own history, we will find old and more recent traditions, which the new generation should assimilate. These traditions speak of iron characters and will, military fortitude and national strength." (Balicki, 1903, p. 90).

The power of the national spirit was highlighted in the neo-romantic mood by the "meteor of Young Poland" and "the genius Pole" - as he was referred to in Berlin - Stanisław Przybyszewski. His observation at the end of World War I was almost metaphysical in nature: "the prophesy of the bard has come true. The greatness of our ancestors deeds made us die at Maciejowice, let ourselves be handcuffed after the defeat at Ostrołęa, ordered us to draw the last drop of blood in the year of 1863, performing deeds heroic beyond all human measure, but it did not allow us to die. This holy, heroic greatness of the deeds of the Polish spirit, the solemnity of its devotion and generous sacrifices of blood and treasure, the almost Christ-like dignity of its martyrdom, are the cornerstone of life." (Przybyszewski, 1917, p. 17).

In turn, Alexander Bruce Boswell, a British historian and sociologist, in his attempt to describe the Polish national character, pointed to tolerance, respect and acceptance for foreign customs, beliefs and cultures, as well as hospitality towards foreigners, which was in stark contrast to the "English contempt for otherness". In his opinion, it originated in the multireligious, multi-cultural and multi-national Republic of Poland of the past and later gave rise to a sense of civilisational community with the whole Europe. Boswell also emphasised the positive aspects of Polish individualism and imagination in private life, as well as impatience towards supervision and discipline. The strong attachment to individual rights, deeply rooted in the Polish character, was shining, in Boswell's words, in the fight against the central, absolute power. This love of individualism on the one hand gave birth to prominent figures, social authorities, and the elites, but, on the other, hindered fostering the solidarity and discipline of the nation. According to the British author, what was also noteworthy about Poles was their imagination, which kindled the thoughts of independence, led to heroic deeds and aroused anxiety about the fate of the homeland in times of occupation. It awakened the "spirit of fierce, persistent resistance", which helped the Polish nation survive the loss of independence and achieve great deeds (Boswell, 1919).

The November of 1918 finally brought freedom and independence. Having great goals in mind, but at the same time aware of possible threats, Poles rushed with enthusiasm, diligence and resourcefulness to rebuild, consolidate and defend its newly regained statehood. With a sense of historic mission, the Polish nation bravely stood up to the deadly threat of the Red Army, demonstrating a strong political instinct, courage, determination and 
resourcefulness, which brought eighteen years of independence of the Second Polish Republic.

A crucial component of the character of the Generation of Independent Poland, though rarely noticed by historians and ethno-psychologists, was honour, both in its axiological dimension of the sense of pride, dignity, nobility, and diligence, as well as in the sense of ethical virtue in people's mentality and the morale of soldiers, shaping consciously determined attitudes and behaviours. Honour was perceived in the national context also by Marshal Józef Piłsudski, who argued that its absence leads to helplessness. His warnings addressed to Polish politicians and military men regarding negotiating both with allies and with hostile powers now seem very accurate. Piłsudski advised never to cross the line when the "honour of the Polish nation" was at stake. The Minister of Foreign Affairs, Colonel Józef Beck heeded this advice in the face of the threat of war in May 1939.

Following the code of honour, deep patriotism, the need to serve the homeland and willingness to make the ultimate sacrifice in its defence were the moral testimony of that wartime generation of "indomitable" people. That generation did not understand the dilemma "to fight or not to fight", as evidenced by the battles fought in September 1939 and in subsequent campaigns of World War II and in the efforts of the Home Army on the barricades during the Warsaw Uprising. The attitude of the young runner of the Home Army's "Kryśka" Unit, and one of the bravest women who took part in the Uprising - Maria Cetys, became a symbol of courage, determination and soldier's honour. Even after she lost her arm, the woman continued to fight. When she was captured by the Germans in Czerniaków and asked: "bist du Banditin?" (“Are you one of the bandits?”), she replied proudly: "I am a soldier of the Home Army", for which she was murdered on the spot (Borkiewicz, 1957, p. 602).

An interesting description of the nature of the Polish soldier was presented by General Gustaw Łowczowski, a man of merit, an officer during three wars, a lecturer at the former War College and a diplomat (Lowczowski, 1968). Referring to the study by Kazimierz Przerwa-Tetmajer O żotnierzu polskim w latach 1795-1915 (The Polish soldier in 1795$1915)^{8}$, Lowczowski accurately observed that the personality of the soldier and the spirit of the army reflect the Polish national character. Taking into account moral factors that are at play during combat, such as honour, sense of duty, discipline, ambition, courage, resistance to

\footnotetext{
${ }^{8}$ K. Tetmajer, O żotnierzu polskim 1795-1915, Naczelny Komitet Narodowy, Oświęcim 1915. This eminent representative of Young Poland did not spare criticism, either, of Polish parochialism and other flaws of Polish "patriotism" (Patryota, Życie" 1897 - Young Poland weekly, Department of Old Prints of the Jagiellonian University).
} 
fear and panic, he presented a very positive characteristic of the Polish soldier, based on his own observations and the opinions of foreign commanders. He also highlighted the features that distinguished Polish soldiers from German, Russian and British ones, including strong sense of patriotism, empathy and sensitivity. Despite the lack of self-control typical of Englishmen, German discipline and Russian fatalism, the Polish soldier emerged victorious in wars due to his patriotism, exceptional individualism, proud ambition, deep faith in eternal life and sense of honour. What in times of peace is seen in negative light, such as pride, exaggerated self-esteem, contentiousness and bravado, on the battlefield can inspire heroic deeds, cleverness on the battlefield and courage even in the face of panic. On the other hand, historical experiences, partitions, and occupations suppressed in the mind of the Polish soldier the subconscious and absolute trust in the leaders and military superiors, which might have given rise to the inclination to criticism and undermining the authority of commanders and their decisions.

When talking about the character of Poles, one cannot overlook the portrait written during the German occupation by the excellent teacher and scout Aleksander Kamiński. He described features considered as typically Polish in an ambivalent way, including their positive and negative aspects. Thus, the author juxtaposed such qualities as the love of freedom and independence with hatred and resistance to any form of subjugation, religious tolerance with bigotry and disdain for the authority. He noticed generosity, sensitivity and hospitality of Polish people in offering refuge to persecuted people, gentleness and kindness of Polish soldiers towards the defeated. On the other hand, he pointed out excessive trust placed in strangers and compliance of Poles, as well as their lack of consistency and exaggerated understanding shown to the defeated or discredited. In bravery, heroism and a distinctive sense of honour, Kamiński saw the ability to perform great deeds, but also the lack of perseverance and certain weaknesses regarding organisational aspects. The author also highlighted the ability of Poles to devote themselves completely to the public and national cause, but, at the same time, he criticised their martyrological snobbery and obscuring economic realities with "patriotic pomposity". Finally, the faith of Poles in the superiority of spiritual forces provided comfort in times of occupation and united them in the hope of better times to come. On the other hand, Kamiński noticed a certain proclivity of Polish people to 
passively surrender to the judgments of Providence in the hope that "it will work out somehow", as well as blind faith in prophecies, fortune-telling and superstitions ${ }^{9}$.

Despite such contradictory description of his compatriots by Kamiński, nowadays in our collective memory we tend to glorify the Independent Poland Generation, the bravery of the nation and the soldiers, ignited by the love of freedom, homeland and the virtue of honour. In the history of the Polish army, we emphasise the courage and determination of Polish soldiers in the fight on all fronts of World War II "for our freedom and yours". It is with great pride that we read words of recognition both from our Allies and enemies. It is worth to recall here the laudatory comments about Polish soldiers in World War II, made by the British military men after the capitulation of the Third Reich. According to the special report by Sir W. Stanley Moss, in a secret ballot voting conducted during a special briefing of 37 British staff officers, a Polish soldier was chosen as the best soldier in the whole allied forces. The man was described as presentable and brave, with a strong sense of individuality, which made him particularly dangerous to the enemy ${ }^{10}$. However, it should be noted that in the axiologisation of Polish national character individualism is also perceived in a pejorative way.

Unfortunately, there are also numerous defamatory statements, harmful stereotypes and lies disparaging Polish involvement in wars, such as mockery of the defenders of Westerplatte and spreading propaganda about Polish cavalry brigades charging German tanks with their sabres or lances in 1939. There are attempts to undermine great national uprisings, such as the Operation "Tempest" and the Warsaw Uprising, to commit to oblivion the bravery and tragedy of Polish soldiers on the Eastern Front, even to question the point of fighting for independence and the Republic of Poland and reduce it to irresponsible spillage of Polish blood in the name of an allegedly naive sense of national honour.

After the defeat of 1939, the government in exile consisting mostly of the pre-war political opposition, found an opportunity for brutal retaliation against the much hated "Sanation", portraying the camp as the perpetrators of the national disaster. In an atmosphere of condemnation, political vetting and discrimination, the stereotypes of cowardly, inept and irresponsible generals and brave but helpless soldiers and civilians were created. What is interesting is that such stereotypes are present to this day in the Polish and Russian historical

\footnotetext{
9 A. Kamiński, Charakter narodowy Polaków, "Biuletyn Informacyjny" no. 21 (125) of 28 May 1942, in: "Przegląd Historyczno-Wojskowy special issue 2, Warsaw 2002, p. 949-951. A. Kamiński's authorship was confirmed by prof. Maria Straszewska - secretary of the editorial office of "Biuletyn"; cf.: S. Wójcik, Charakter narodowy Polaków czasu II wojny światowej, "Rocznik Nauk Społecznych;, vol. XXX, of January 2002, p. 93. ${ }_{10}$ Werdykt trzydziestu siedmiu, in: P. Szudek, Wspomnienia oficera do zadań specjalnych, foreword by $\mathrm{R}$. Kaczorowski, elaboration and afterword by K. Komorowski, Warsaw 2012, p. 237-239
} 
narratives. In turn, Germans, from the beginning of World War II, disseminated a false image of Poles, defaming their national character, mocking the alleged backwardness, stupidity and reckless bravado (including in the context of the aforementioned charges at tanks), their bloody heroism, supposedly meaningless for the Battle of Monte Cassino, and finally the lack of honour and integrity demonstrated through the alleged crimes against German prisoners by soldiers of General Stanisław Maczek or the inhuman treatment of Germans expelled from the lands lost by Germany after the Second World War and "pleasure derived from someone else's misfortune" (Schadenfreude).

Regardless of the motivation of the authors, the consequence of such harmful opinions was the disruption of the self-stereotype of Poles in the collective memory of Polish martyrdom, trauma, harm, suffering, devastation, but also determination, honour, heroism, sacrifice, solidarity in misfortune, resistance to terror and fierce opposition against invaders. The more the memory of glorious moments in history strengthens the national pride, bordering with self-love and lack of critical thinking, the more painful and harmful any unfavourable stereotypes and critical opinions seem.

The most traumatic disappointments in the historical memory of Poles were those after the betrayal by Poland's closest allies: France, Great Britain and the United States. The famous call "For our freedom and yours", accompanying Polish patriots through the nineteenth and the middle of the twentieth century, and paid with our soldiers' blood, turned out to be an illusion. The subsequent historical breakthroughs of 1920, 1939 and 1945 took place in Poland that was left alone, even betrayed by its allies and comrades in arms.

The nation that was the most loyal member of the Grand Alliance against the Axis, in a vain hope that the shed Polish blood would convince the great powers to help restore the entire, independent Poland, experienced instead the bitterness of defeat and humiliation, not only at the hands of the new Soviet hegemon, but also, and perhaps above all, at the hands of the closest allies! When the fate of post-war Europe and Poland was being decided, US President Franklin D. Roosevelt, who called himself a friend of Poland, invited Stalin to his private residence during a conference in Tehran to ask the Russian dictator to keep the decision about incorporating the eastern part of Poland into the USSR and maintaining the rest under Soviet influence confidential, as he needed the votes of Polish Americans for reelection. In turn, when the acting Commander-in-Chief, General Władysław Anders, asked British Prime Minister Winston Churchill for support at a decisive moment for the Polish cause, reminding him of the Polish soldiers' contribution to the victory over Germany, Churchill ordered him to "take back his divisions". Unfulfilled noble intentions, bitter 
disenchantments with comrades in arms and lack of solidarity with freedom fighters are a painful lesson in political and military realism and speak of the selfishness of superpowers in their actions and strategies. The question remains how these experiences - well established in the national memory - influenced the Polish character and the attitudes of Poles after the war. Did they reinforce selfish inclinations and limited emotional aspects in favour of rational ones?

It turned out that although the year 1945 ended the war, it did not end the national tragedy for Poles. It was the beginning of a new reality, marked by a hegemonic and geopolitical breakthrough, which divided the world with an "iron curtain" into two opposing systems: the Eastern bloc - subject to the Soviet regime, and the camp of Western democracies with the leading role of the United States. The decimated, wounded and shattered Polish nation was subjected to a new test of enslavement, when the former allies now became hostile powers, and the former mortal enemy or, at best, the "ally of our allies" - the Soviet Union - became a political, social and cultural model. The goal of the new authorities was revolution by imposing a communist regime and creating a new type of society and state. The Polish nation was subjected to persistent indoctrination and the political history was transformed so as to refute the Polish pro-independence and democratic traditions and impose new models according to the "socialist morality".

What also had an unquestionable impact on the national character and bond of the Polish nation were territorial changes in 1945, when seven eastern provinces were lost in exchange for the so-called Recovered Territories to the west and north of Poland. Due to the loss of a third of the population, the demographic potential diminished considerably. Those who managed to survive occupation, war and the post-war communist terror, now faced the dilemma: what to do next? The vast majority, despite the tragedies experienced, showed an extraordinary will to live on a normal, peaceful and stable life, as well as amazing entrepreneurship and resistance to the hardships of everyday life. The "Indomitable Soldiers" went "underground" to continue their fight for the independence and sovereignty of the homeland. However, they, too, subjected to the wicked mechanisms and terror of the new authority and aware of the enormous devastation it brought, chose the path of "Wallenrodism" seemingly joining the mainstream, "lawful" life. A generation of young patriots trying to reconcile with the past, while being tragically tested by the contemporary situation, doomed to the foreign domination of the Soviets, was trying to find a place for themselves in this new state. Those who were unable to do that were trying to escape to the West. 
At the same time, great population migrations were underway due to the changed borders, such as the expulsion of Germans, the transfer of Ukrainians and Belarusians to the USSR and the repatriation of Poles from the east, which, combined with the almost complete extermination of Jews in Poland, resulted in the ethnic homogeneity of the society $(97 \%$ of Poles). To illustrate the tragic demographic repercussions of the war, it is enough to mention 1.2 million tuberculosis sufferers, 1.5 million war and concentration camp invalids, 1.1 million orphans, thousands of people suffering from depression and mental disorders, several hundred thousand sent to Soviet labour camps or imprisoned and tortured in Poland, as registered in 1946.

At that time, the burden of maintaining national identity, Polishness and morale fell on the elites. It is the eminent individuals, moral, political, scientific, artistic and military authorities with the former intelligentsia (teachers, clergy, officers, journalists, intellectuals, lawyers), representing the Independent Poland Generation, constituted the soul and moral backbone of the nation. Despite immense human losses during the war (approx. 50\%) and post-war attempts to paralyse and subdue it, the Polish intelligentsia played a role as the educator of the nation. The outstanding contribution of the Polish emigration in this regard cannot be overestimated.

Unfortunately, the lack of methodological research on the Polish national character in times of the Polish People's Republic makes it impossible to fully analyse the Polish personality and mentality of that time. As Andrzej Wierzbicki rightly observes, after the last war the evaluation of the Polish national character suffered a downward tendency (Wierzbicki, 2010, pp. 275-280). On the one hand, there were axiological aspects related mainly to the tragedy of war and burdened with a new system of values imposed by the Soviet regime. On the other hand, the characterological reflection of the time had a clear pragmatic side based on the analysis and assessment of the attitudes of the society, which was used for the purposes of indoctrination, reshaping the politics of memory and education to bring up the society according to the expectations of the new authorities.

At the same time, national identity, understood as a sense of national community, was shaped by propaganda and evoking a constant feeling of threat from the West, especially from the Federal Republic of Germany, allegedly seeking retaliation and revision of its borders. In a society which still had a vivid memory of the atrocities of war, terror and genocide, it was not difficult to instil the sense of anti-German nationalism. The atmosphere of external threats undoubtedly had a considerable influence on the mentality and attitudes of Polish people, especially leading to the feeling of resignation and acceptance towards the political, social and 
economic reality in the country at that time. In the character of Poles from that time one could find such elements as suffering, martyrdom and injustice, heroism, inferiority complexes (not only related to history), "collectivity" in everyday life (best expressed by the line from Vladimir Mayakovsky's poem in honour of Lenin - "The individual is nonsense, the individual is nothing") at the expense of traditional individualism and persistently imposed concepts of social classes. But above all else, one could find there religiousness with faith, hope and trust in the intervention of the omnipotent God. The condemnation of the holy right to private property and the Polish way of life, the cult of the aforementioned "class" system and the utopian ideals putting the workers and peasants alliance at the helm and prioritising the so-called internationalism, gave rise to existential nihilism with the relativisation of values, which resulted in hypocrisy and dishonesty, manifested by the recognition of "two truths": the official interpretation and unofficial beliefs based on family traditions, the memory of the pro-independence circles and the teachings of the Church. The depravation of social and professional life was accurately summed up by an outstanding lawyer and penal law expert, prof. Krystyna Daszkiewicz. In her Treatise on Poor Work, she stigmatised the flaws and sins of her compatriots from the communist period. She wrote about the bands of swindlers, whom she called "kuglarze" (lit. jugglers), following Samuel Bogumił Linde’s definition: "kuglarz - a hypocrite, a swindler who is bluffing and pulling the wool over people's eyes, mocking them, one who sells mice dung as pepper, and a cat as a hare" (Daszkiewicz, 1983, pp. 7-20).

Changes in the Polish national character after World War II, with the suppression of traditional values by the authorities, were also triggered by the new geopolitical position of the country.

The Polish Pope John Paul II, who was considered as the reviver of the spirit of the Polish nation, played a historical role in stopping these harmful trends. Also, for the interpretation and teaching of Polishness, the contribution of the Primate of the Millennium, Cardinal Stefan Wyszyński, cannot be emphasised enough. Cardinal Wyszyński ardently advocated the idea of uniting the nation against indoctrination, sovietisation through the synthesis of religiousness, patriotism and freedom movement (Wierzbicki, 2016, pp. 26-33). Finally, one cannot forget about by the phenomenon of the "Solidarity" with its millions of members. There was no alternative to the "path of hope", leading to freedom, democracy and the rule of law. The authorities could no longer maintain the old order, and the society did not want to continue living like this. 
The historic compromise led to a bloodless geopolitical and political breakthrough. The definition of a national community put forward by the renowned sociologist Morris Ginsberg proved to be accurate. Ginsberg described it in terms of the uniformity of character traits, which are supposed to be based on feeling, belief and collective creativity, with emotional, volitional and intellectual aspects (Bieleń, 2015, pp. 127-140). It is the deeds, and not the perception or evaluation, that are the real test of the national character.

The historic breakthrough of 1989 caused not only the fall of the Soviet hegemon and the return of Poland to the world of Western democracies, bringing a political transformation of the state and the army, but also, and perhaps most importantly, it triggered changes in the value system, restoring people's faith and hope for a better future. The awakening of the truly Polish soul, enthusiasm with regained freedom, attempts to get rid of the deep divisions of the society into "us" and "them" was accompanied by a renewed sense of national pride, creative optimism and a revival of the independence traditions in the nation and the army. A meaningful message in this regard was delivered by John Paul II to the Polish Army on 2 June 1991. Reminding the audience that devotion to the homeland means love and sense of service, the Pope emphasised how much the glorious traditions of the Polish army oblige one to patriotism and service to the homeland ${ }^{11}$. This teaching found its way to the hearts and minds of millions of Poles who had been longing to return to their national roots, to have the historical truth restored and the falsehood of the official interpretation of the Polish People's Republic exposed.

Patriotic sentiments and the outbreak of civil society defined a new programme of patriotic traditions in national education. A battle began for truth in the politics of memory of the state, with the participation of scientists, journalists, teachers, officers and the clergy. The new methodology of historical research, the abolition of political censorship, the release of political prisoners, and the active participation of veterans' circles, opened the way for independent journalism and literature, which merged with works created by the Polish emigration into a single stream of Polish historiography.

However, restoration of the historical memory and consciousness to the society and the army was by no means facilitated by the mechanisms of a new democracy favouring the dualism of the world of values, reminiscent of the old establishment embedded in the revolutionary tradition. It is necessary to separate the evaluation of the Polish People's Republic system from the behaviour, morale, character, mentality and attitudes of the society. 
Opinions that condemn both the system and the society at the same time are unjustified. After all, it was the Polish nation that achieved a breakthrough, which drew admiration from the whole world, who was wondering "how did you do it?".

Attempts at the evaluation of the Polish nation with its virtues and flaws have on numerous occasions aroused disputes and controversies. An unresolvable dilemma presented itself: either to distance oneself from the past and focus on the future (the concept of the socalled thick line) or rather focus on memory, verification, vetting and punishment (the concept of the so-called zero option). Settling accounts with the criminals of the People's Republic of Poland became part of the patriotic education of the nation. Representatives of the "Solidarity" movement who took over the ministries of education and defence started to restore true history and tradition. A milestone for revving the military spirit was the establishment of the Polish Army Day on 15 August (on the anniversary of the great victory against the Soviet invasion in 1920), the adoption of a new military oath with allegiance pledged to the communist hegemon left out, the restoration of original symbols (e.g. the eagle was again presented in the crown), the adoption of great national heroes as patrons of military units, and finally the restoration of traditional banners, changes in the commemoration tablets of the Tomb of the Unknown Soldier and in the regimental halls of history.

\section{Conclusions and perspectives}

Research conducted in the period of the political transformation confirms that the basic criterion of Polish identity was emotional identification with the homeland. Its cultural aspect was the knowledge and preservation of Polish traditions - pride in national and military victories in the past and sensitivity to any slander directed against them, as well as the celebration of customs and state-military ceremonies of the Third Republic of Poland (Błuszkowski, 2005, pp. 120-140). During the period of the major geopolitical breakthrough (transition from the Warsaw Pact to NATO), when the country was in the so-called grey security zone, the patriotic spirit of the nation and the morale of the army were the basic guarantor of the state's defence capabilities.

Therefore, one can hardly accept the opinion that the national identity of Poles in the times of political transformations lacked references to common historical roots and favoured distancing oneself from the past (Tarasiewicz, 2011, p. 43). In his Essay on the Polish Soul,

\footnotetext{
${ }^{11}$ Pope John Paul II. Speech delivered during a meeting with the Polish Army in Koszalin on 2 June 1991, Fundacja Opoka.org.pl, published on 17 April 2002.
} 
Ryszard Legutko drew attention to the anti-historical attitude of Poles in the Third Republic. In his opinion, breaking ties with the country's past was the result of the indoctrination and the distorted politics of memory imposed under the communist rule (Legutko, 2008, pp. 13-14), which is a misconception. As has already been mentioned, the first years of the transformation brought a spontaneous, impatient movement to restore the true history and the so-called "extraordinary revision", which was supposed to achieve this goal with the help of historians, teachers, the Catholic church, journalists and veterans. It was only after some time, as Maria Janion observes, that the romantic spirit accompanying the changes was replaced by sober pragmatism, disturbed by the delusions of the times of social insecurity and symptoms of frustration (Janion, 1996, pp. 14-15). Changes in the national mentality were also triggered by the processes of globalisation, Europeanisation, unification and tolerance in the neoliberal spirit. Concern for material aspects in the world of existential threats was conducive to ethical relativisation, freedom of moral choices and the decline of collective memory. As a result, historical patriotism and pride in the past of one's homeland were sometimes regarded as a whim of romantic archaism, while the virtue of honourable conduct was even linked with Quixotism. These virtues were overshadowed by pragmatic cunning and opportunism. The traumatic past of Poland and the country's historical burdens in its relations with the neighbouring states appeared to hamper the process of building a new European order and strengthening international cooperation. However, contrary to nihilists' predictions with their neo-liberal tendency to dissociate themselves from "historical whims", the national past invariably keeps drawing the attention of the Polish society. Despite the collision of political modernism with history, we still live "the past in the present".

The individualism typical of contemporary Poles along with their resourcefulness invariably collides with the lack of self-organisation, inability to initiate joint, grass-root actions and rejections of authorities. One can venture an opinion that the current individualism has two faces: on the one hand, social activity, selfishness, cunning, competition (prioritising one's own interests in the face of threat) and, on the other, humanitarian solidarity, openness, belief in the superiority of cooperation over divisions. It seems that the spectre of the former social collectivity and the mind-set of traditional individualism still clash in the national mentality.

What remains a special feature of the Polish national character is religiosity. It is sometimes used to identify the spirit of the nation with the Catholic faith according to the traditional self-stereotype of a Pole-Catholic (Błuszkowski, 2005). Such a perception promotes the messianic doctrine under the slogan "Poland as the Christ of Europe". The 
return to the romantic ideology of an oppressed nation, aware of its own mythologised moral superiority, as well as the need to mobilise against the threats of Europeanisation and unification, seems to regarded as the key to political triumph. Is a kind of revolution necessary, then, for the moral revival of the nation?

It looks like the teachings of the great reviver of the Polish spirit, John Paul II, who from the beginning of his pontificate was advocating a new evangelisation of Europe beyond political and national divisions, in the unity of a "spiritual community", have largely been forgotten (Wierzbicki, 2016, pp. 26-33). In his last work, Memory and Identity, John Paul II teaches us that the essence of Polishness is, in fact, pluralism, and not narrow-mindedness. ${ }^{12}$ The vision of patriotism and spirituality of Poles, according to this teaching, breaks with the stereotype of a "Pole-Catholic". By showing his respect for the patriotism of Polish Jews and Evangelicals, the Pope clearly distanced himself from the ideology of nationalism, and especially ethnocentrism, which gives rise to a feeling of superiority, contempt and hatred towards others through national egoism overcome by the idea of messianism. Cyprian $\mathrm{K}$. Norwid warned against this tendency already during the times of partitions, when he wrote that: "a noble man could not live one day in a homeland whose happiness was not only a percentage of the happiness of humanity".

The "examination of conscience" and warnings for the Polish nation allow for moderate optimism in thinking about the state's defence capabilities.

\footnotetext{
${ }^{12}$ Jan Paweł II, Pamięć i tożsamość, Kraków 2005, p. 92.
} 


\section{References}

Ardant d'Picq, CH.J. (1927) Studium o walce, Warszawa.

Balicki, Z. (1093) Egoizm narodowy wobec etyki, Lwów.

Barker, E. (1963) Charakter narodowy i składniki go kształtujace: składniki duchowe, element polityczny, rząd i prawo, in: Współcześni historycy brytyjscy. Wybór pism, Londyn.

Bieleń, S. (2015) 'O pułapkach charakteru narodowego. Społeczna strategia narodowa', Polityka Polska, 1 maja 2015.

Błuszkowski, J. (2005) Stereotypy a tożsamość narodowa, Warszawa.

Bocheński, A. (1972) Rzecz o psychice narodu polskiego, Warszawa.

Bocheński, J. M. (1994) Patriotyzm, męstwo, prawość żotnierska, Komorów.

Borkiewicz, A. (1957) Powstanie Warszawskie. Zarys działań natury wojskowej, Warszawa.

Boswell, A. B. (1919) Poland and the Poles, London. Methuen.

Clausewitz, C. (1995) $O$ wojnie, Lublin.

Gintel, J. (1971) Cudzoziemcy o Polsce. Relacje i opinie, Kraków.

Daszkiewicz, K. (1983) Traktat o złej robocie, Poznań.

Foucault, M. (1993) Nadzorować i karać, Warszawa.

Ginsberg, M. (1947) Reason and unreason in society, London: The London School of Economics and Political Science.

Handelsman, M. (1928) Historyka. Zasady metodologii poznania historycznego, Warszawa.

Handelsman, M. (1924), Rozwój narodowości nowoczesnej, Warszawa.

Handelsman, M. (1928) Historyka. Zasady metodologii poznania historycznego, Warszawa.

Jezierski, A. (2003) Historia Polski w liczbach. Państwo i społeczeństwo, t. I, Warszawa: Główny Urząd Statystyczny.

2012 Informacja o rozmiarach i kierunkach emigracji z Polski, Warszawa: Główny Urząd Statystyczny - Departament Badań Demograficznych.

Janion, M. (1996) Czy będziesz wiedział co przeżyteś, Łódź.

Jaxa-Bykowski, L. (1938) Charakter i Wola, Warszawa: F. Herod.

Kamiński, A. (2002). 'Charakter narodowy Polaków, Biuletyn Informacyjny, nr 21 (125) z 28 V 1942 r., In: „Przegląd Historyczno-Wojskowy nr specjalny 2, Warszawa.

Komorowski, K. (2016), 'Blaski i cienie strategii bezpieczeństwa i obronności III Rzeczypospolitej’, in: Trejnis, Z. Mariniak M. (Eds) Obronność państwa. Strategie oraz systemy bezpieczeństwa i obronności, Torun.

Komorowski, K. (2019) 'Dewiza „Bóg-Honor-Ojczyzna” jako wartość budząca i krzepiąca ducha żołnierza polskiego', in: Siła ducha. Kapelani Wojska Polskiego w służbie pokoju, bezpieczeństwa i wolności narodów' Warszawa.

Komorowski, K. (2016) 'Kłopoty z najnowszą strategią bezpieczeństwa RP', Przegląd Nauk o Obronności”, 2016, 1-2.

Komorowski, K. (2011) 'Refleksja metodologiczna do studiów nad Wojskiem Polskim' Przegląd Historyczno-Wojskowy”, 1. 
Komorowski, K. (2019) 'Aspekt historyczny potencjału obronnego Polski’ Stańczyk, K. (ed.) in: Potencjat obronny Rzeczypospolitej, Warszawa.

Legutko, R. (2008) Esej o duszy polskiej, Kraków.

Lelewel, J. (1964) Dzieła, t.2, cz.1, Warszawa.

Łepkowski, T. (1957) Polska - narodziny nowoczesnego narodu 1764-1870, Warszawa.

Łowczowski, G. (1968) Polak jako żołnierz, Londyn.

Magnonii U. (1751) Nocticum Sarmaticarium Vigiliae, Braniewo - Warszawa 1751;

Mignoni, U. and Grabowski, A. S. (1751). Ubaldi Mignonii de Cler. Reg. Sch. Piaru[m] Presbyteri [...] Noctium Sarmaticarum Vigiliae. Braniewo: Drukarnia Jezuitów.

Marczak, J. et al. (2013) Doświadczenia organizacji bezpieczeństwa narodowego Polski od X do XX wieku, Warszawa.

Mączak, A. (1994) Klientela. Nieformalne systemy władzy w Polsce i Europie XVI-XVIII w., Warszawa.

Moczulski, L. (2008) 'Polska pomiędzy Niemcami a Rosją. Mit geopolityczny a rzeczywistość' in: Eberhardt P. (ed.) Problematyka geopolityczna ziem polskich, Warszawa.

Norwid, C. (1973) Co to jest Ojczyzna. Pisma wszystkie, Warszawa.

Szwed, R. Dyczewski, L. Szulich-Kałuża, J. (eds.) (2010) Odmiany tożsamości, Lublin.

Parys J. (1992) 'Wojsko i obronność. Historia, współczesność, proporcje. Wywiad Ministra Obrony Narodowej dla Redakcji „Wojskowego Przeglądu Historycznego” z 4.02.1992 r.', Wojskowy Przeglad Historyczny, 1/2.

Piaskowska-Majzel, M. (2007). Jan Pawet II, Pamięć i Tożsamość, Szczecin: Centrum Doradztwa i Doskonalenia Nauczycieli.

Piłsudski, J. (1937) Pisma zbiorowe, t.VIII, Warszawa 1937.

Przybyszewski, S. (1922) Szlakiem duszy polskiej, Poznań.

Smith R. (2010) Przydatność siły militarnej. Sztuka wojenna we współczesnym świecie, Warszawa.

Spisy ludności Rzeczypospolitej Polskiej 1921-2002, Polskie Towarzystwo Demograficzne Główny Urząd Statystyczny, Warszawa 2002.

Stojanowski, K. (1939) 'Polsko-niemieckie zagadnienia rasy, Poznań, Katowice.

Sułek, J. (2017) Traktat Graniczny RP-RFN z 14 listopada 1990 roku jako ostatnie zamknięcie polsko-niemieckiego sporu o granicę po II wojnie światowej (ze wspomnień głównego negocjatora po 25 latach)', Niepodległość i Pamięć, 1.

Szudek P. (2012) Werdykt trzydziestu siedmiu, w: Wspomnienia oficera do zadań specjalnych, przedmowa R. Kaczorowskiego, Warszawa.

Świniarski J. (2009) ‘Bezpieczeństwo, a charakter narodowy Polaków’, in. Szczurek, T. (ed.) Zagadnienia bezpieczeństwa w problematyce charakteru narodowego Polaków, Warszawa: Wojskowa Akademia Techniczna.

Tarasiewicz, P. (2011) 'Specyfika Polaków jako narodu', Cywilizacja”, 37.

Tetmajer, K. (1915) O żołnierzu polskim 1795-1915, Oświęcim: Naczelny Komitet Narodowy.

Tischner, J. (2001) Charakter narodowy, „Recogito” 9, maj-czerwiec 2001 (http://www. recogito.pologne.net/recogito_9 (obserwatorium 1.htm). 
Ustawa Rządowa. Prawo uchwalone. Dnia 3 Maja roku 1791 w Warszawie, Volumina Legum, t. IX, Kraków 1889;

Szudek, P. (2012) 'Werdykt trzydziestu siedmiu', in: Szudek, P. (ed.). Wspomnienia oficera do zadań specjalnych, przedmowa R. Kaczorowskiego, Warszawa.

Wierzbicki, A. (2010) Spory o polską duszę. Z zagadnień charakterologii narodowej w historiografii polskiej XIX i XX wieku, Warszawa.

Wierzbicki, M. (2016) 'Piastowski Wyszyński, Jagielloński Wojtyła', Więź, Spring 2016.

Wójcik, S. (2002) 'Charakter narodowy Polaków czasu II wojny światowej’ Rocznik Nauk Społecznych, t. XXX, z. 1.

Wright, Q. (1983) A Study of War, Chicago.

Wrzesiński, W (1884) 'Badania nad charakterem narodowym Polaków. Dyskusja i podsumowanie obrad' Komunikaty Warmińsko-Mazurskie, 1-2.

Szczurek, T. (2009) Zagadnienia bezpieczeństwa w problematyce charakteru narodowego Polaków, Warszawa: Wojskowa Akademia Techniczna. 